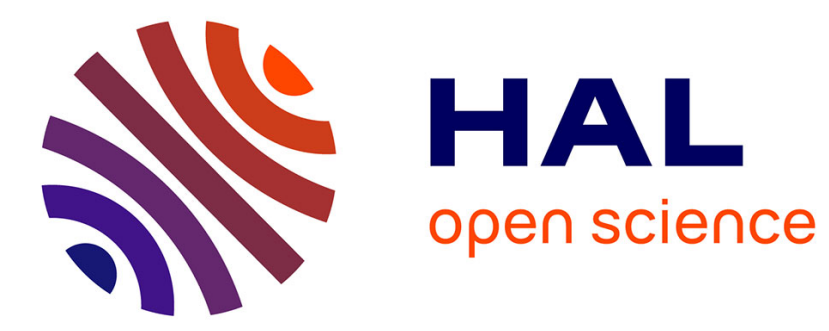

\title{
105 Sexual dimorphism in equine D8 blastocysts (abstract)
}

\author{
E. Derisoud, L. Jouneau, C. Dubois, A. Margat, C. Gourtay, C. Archilla, Y. \\ Jaszczyszyn, M. Dahirel, N. Daniel, N. Peynot, et al.
}

\section{- To cite this version:}

E. Derisoud, L. Jouneau, C. Dubois, A. Margat, C. Gourtay, et al.. 105 Sexual dimorphism in equine D8 blastocysts (abstract). Journal of Equine Veterinary Science, 2021, 100, pp.103568. 10.1016/j.jevs.2021.103568 . hal-03288513

\section{HAL Id: hal-03288513 https://hal.inrae.fr/hal-03288513}

Submitted on 16 Jul 2021

HAL is a multi-disciplinary open access archive for the deposit and dissemination of scientific research documents, whether they are published or not. The documents may come from teaching and research institutions in France or abroad, or from public or private research centers.
L'archive ouverte pluridisciplinaire HAL, est destinée au dépôt et à la diffusion de documents scientifiques de niveau recherche, publiés ou non, émanant des établissements d'enseignement et de recherche français ou étrangers, des laboratoires publics ou privés. 
Journal of Equine Veterinary Science 100 (2021) 103568

https://doi.org/10.1016/j.jevs.2021.103568

\title{
105 Sexual dimorphism in equine D8 blastocysts
}

\author{
E. Derisoud ${ }^{1,2, *}$ L. Jouneau ${ }^{1,2}$, C. Dubois ${ }^{3}$, A. Margat ${ }^{4}$, C. Gourtay ${ }^{4}$, C. Archilla ${ }^{1,2}$, \\ Y. Jaszczyszyn ${ }^{5}$, M. Dahirel ${ }^{1,2}$, N. Daniel ${ }^{1,2}$, N. Peynot ${ }^{1,2}$, L. Briot $^{4}$, F. De Geoffroy ${ }^{4}$, \\ L. Wimel $^{3}$, V. Duranthon ${ }^{1,2}$, P. Chavatte-Palmer ${ }^{1,2}$
}

${ }^{1}$ Université Paris-Saclay, UVSQ INRAE, BREED, Jouy-en-Josas, France

${ }^{2}$ Ecole Nationale Vétérinaire d'Alfort, BREED, Maisons-Alfort, France

${ }^{3}$ IFCE, Plateau technique de la Valade, Chamberet, France

${ }^{4}$ IFCE, Plateau technique du Pin, Exmes, France

${ }^{5}$ Institute for Integrative Biology of the Cell (I2BC), UMR 9198 CNRS, CEA, Paris-Sud University, Gif-sur-Yvette, France

In mammals, male embryos grow faster. Equine embryo size is highly variable for same developmental stage, with no reported relation to embryo sex nor gene expression. Our objective was to evaluate gene expression sexual dimorphism on equine D8 blastocysts. Non-nursing, Saddlebred mares located on 2 experimental farms were inseminated with the semen of one unique stallion per farm. At $8 \mathrm{~d}$ post ovulation, 17 and 11 embryos from each farm, each from a different dam, were recovered by uterine flushing and bissected to obtain samples of pure (TE) or inner cell mass enriched (TE-ICM) trophoblast. RNA expression was analyzed separately in the TE-ICM and the TE of 16 female and 12 male embryos using paired end, non-oriented RNA sequencing (Illumina, NextSeq500). To discriminate gene expression in the ICM from that in the TE, deconvolution (DeMixT R package) was used on the TEICM data. Differential expression was analyzed (DESeq2) with farm and embryo size as cofactors using a false discovery rate (FDR) < 0.05 cutoff. Gene Set Enrichment Analysis was performed using the KEGG and GO BP databases. Out of the 13,786 and 13,210 genes expressed in ICM and TE, respectively, only 184 (51.1\% on X chromosome) in ICM and 415 (39.0\% on X chromosome) in TE were differentially expressed, with 111 genes in common. Overall, 145 in ICM and 312 in TE genes were significantly upregulated in female. As reported in bovine embryos, glucose-6-phosphate dehydrogenase
(G6PD) was upregulated in female ( $\log 2$ Fold Change $=0.96$ in ICM and 0.83 in TE; both FDR $<0.001$ ). G6PD is required for detoxification of oxygen radicals that have both cellular damage and growthstimulant effects. Reduced levels of oxygen radicals have been hypothesized to be responsible for the growth delay in female bovine embryos. In ICM cells, 16 and 1 gene sets were enriched in male embryos in GO BP and KEGG, respectively while 3 KEGG pathways were enriched in female ICM. In the TE part, 27 and 6 gene sets were enriched in male embryos in GO BP and KEGG, respectively, while no pathway was enriched in female embryos. Biological processes enriched in male embryos are mostly common between ICM and TE and are related to translation and spliceosome, ribosome biogenesis, mitochondrial function, cytoskeleton organization and amino acid metabolism. Pathways that were only enriched in male ICM relate to potassium ion homeostasis while in TE, they relate to protein export. In females, enriched pathways in ICM were related to Krebs cycle, glycosaminoglycan degradation and lysosome. Thus, although no growth retardation has been observed in equine female embryo, sexual dimorphism in gene expression of genes unrelated to the sex chromosomes is observed.

Keywords: Embryo, Horse 